\title{
Taxonomic identity of Crepidiastrum xnakaii recorded on Hongdo Island
}

\author{
Young-Jong JANG and Byoung-Hee CHOI* \\ Department of Biological Sciences, Inha University, Incheon 22212, Korea \\ (Received 9 August 2021; Revised 31 August 2021; Accepted 11 September 2021)
}

\begin{abstract}
The plant known as "Hong-do-go-deul-ppae-gi" on Hongdo Island, belonging to the genus Crepidiastrum, has been recorded as $C$. $\times$ nakaii, a hybrid between $C$. denticulatum and C. platyphyllum. During a survey of the flora of Hongdo Island, we reexamined the taxonomic identity of "Hong-do-go-deul-ppae-gi". The morphological traits, geographical distribution, and internal transcribed spacer (ITS) sequences of "Hong-do-godeul-ppae-gi" were compared to related species within the genus. A morphological examination revealed that the plant was similar to $C$. lanceolatum in that it has subshrub stems with caudex stout, 8 inner involucrals bracts, and 10 to 12 florets. In contrast, similarities to $C$. denticulatum were observed in terms of radical leaves deciduous in the flowering period, cauline leaves membranous with acute serrations, and beaked achenes. Furthermore, $C$. denticulatum and C. lanceolatum grew on Hongdo Island and nearby areas, but C. platyphyllum was not distributed in these areas. The results of morphological and distributional investigations revealed that the Hongdo Island plant should be regarded as $C$. $\times$ muratagenii, a hybrid between $C$. denticulatum and C. lanceolatum, not $C$. $\times$ nakaii, which is a hybrid between $C$. denticulatum and C. platyphyllum. However, the resolution of the ITS sequences was insufficient such that we could not separate the examined species.
\end{abstract}

Keywords: Crepidiastrum ×muratagenii, Crepidiastrum, geographical distribution, Hongdo Island, morphological traits

The distribution of Hong-do-go-deul-ppae-gi was first recognized in Korea by identifying the specimen (Ishidoya, $T$. \& T. H. Chung $3741 \mathrm{TI})$ collected by T. Ishidoya on Hongdo Island as Paraixeris denticulato-platyphylla (Makino) Nakai, a hybrid of Paraixeris denticulate Nakai [= Crepidiastrum denticulatum (Houtt.) J. H. Pak \& Kawano], and C. lanceolatum var. latifolium Nakai [= C. platyphyllum (Franch. \& Sav.) Kitam.]. Later, it was treated as $\times$ Crepidiastrixeris denticulato-platyphylla (Makino) Kitam. by Kitamura (1937). It seems to have been named Hong-do-go-deul-ppae-gi because it was first collected on Hongdo Island (Lee, 1969; Lee, 1996). However, the above scientific name was illegitimate (ICN H6.2. and H.9.1.). Hence, it was corrected to Crepidiastrum $\times$ nakaii $\mathrm{H}$. Ohashi \& K. Ohashi, as the two parent species were treated as Crepidiastrum by Pak and Kawano (1992) (Ohashi and Ohashi, 2007). Saito et al. (2006) reported that $C$. $\times$ nakaii occurs in the area where the parents occur sympatrically, and $C$. $\times$ nakaii shows repeated frequent hybridization between the parent taxa as a result of an incomplete breeding barrier between the two taxa. However, there is disagreement as to whether or not $C$. platyphyllum is distributed in Korea (Ohwi, 1965; Koyama, 1995; Kadota et al., 2017). Furthermore, Lee (1996) described Hong-do-go-deul-ppaegi as a hybrid of $C$. denticulatum and $C$. lanceolatum. Therefore, controversy exists regarding the identity of this plant.

Natural hybridization is a frequent evolutionary phenomenon in flowering plants (Grant, 1981), playing an important role in the formation of new species (Arnold, 1997; Rieseberg, 1997; Seehausen, 2004). Under the limited migration from the continent, species richness of insular flora can be increased via hybridization which may lead to the generation of new species with novel combinations of potentially advantageous parental traits in the new environment (Francisco-Ortega et al., 1996; Brochmann et al., 2000; Jorgensen and Olesen, 2001; FuertesAguilar et al., 2002; Howarth and Baum, 2005). Because of the importance of plant hybridization in evolution, it is of great importance to accurately identify hybrid individuals.

\footnotetext{
*Author for correspondence: bhchoi@inha.ac.kr
} 
To determine the taxonomic identity of Hong-do-go-deulppae-gi, this study examined its morphological characteristics and distribution, and analyzed nuclear ribosomal DNA internal transcribed spacer (ITS) sequences with its related species in the genus Crepidiastrum.

\section{Materials and Methods}

\section{Morphological observation and survey of geographical distribution}

To compare the morphological characters of Hong-do-godeul-ppae-gi and its closely related taxa, we collected specimens from Hongdo, Jindo, and Geomundo Islands in Jeollanam-do Province, South Korea, and deposited them in the Herbarium of Inha University (IUI). In addition, we examined additional specimens throughout the Korea National Biospecies Information System (http://www.nature.go.kr). For identification, reference was made to Kitamura $(1937,1955)$, Pak and Kawano (1992), and Ohashi and Ohashi (2007). Distribution data were collected from the Global Biodiversity Information Facility (GBIF) (http://www.gbif.org), the Korea National Biospecies Information System (http://www.nature.go.kr), Science Museum Net (http:// science-net.kahaku.go.jp), and the Chinese Virtual Herbarium (http://www.cvh.ac.cn).

\section{DNA extraction and PCR amplification}

Total genomic DNA was extracted from dried leaf materials with silica gel (deposited in the herbarium of Inha University, IUI) using the DNeasy Plant Mini Kit (QIAGEN, Hilden, Germany) according to the manufacturer's instructions. The

Table 1. List of species used for the Internal Trnascribed Spacer (ITS) sequences analysis with voucher and GenBank accession numbers.

\begin{tabular}{|c|c|c|c|}
\hline Taxon/locality & Voucher & $\begin{array}{l}\text { GenBank accession } \\
\text { No. }\end{array}$ & Reference \\
\hline \multicolumn{4}{|c|}{ Crepidiastrum denticulatum (Houtt.) J. H. Pak \& Kawano 이고들빼기 } \\
\hline Mt. Dongseogsan, Jindo, Jeollanam-do, Korea & D. P. Jin 2010016 (IUI) & MW938634 & This study \\
\hline Gitdaebong, Hongdo Island, Sinan-gun, Jeollanam-do, Korea & Y. J. Jang 201028-11 (IUI) & MW938645 & This study \\
\hline Nagahama, Kanagawa, Honshu, Japan & N1-PR 1194 (TNS) & AY876275 & Saito et al. (2006) \\
\hline Hubei, Shenlongjia, China & Y. L. Peng 989-7 (CDBI) & KC968062 & Peng et al. (2014) \\
\hline \multicolumn{4}{|l|}{ Crepidiastrum lanceolatum (Houtt.) Nakai 갯고들 빼기 } \\
\hline Geomundo Island, Yeosu-si, Jeollanam-do, Korea & Y. J. Jang 201020-3 (IUI) & MW938639 & This study \\
\hline Geomundo Island, Yeosu-si, Jeollanam-do, Korea & Y. J. Jang 201020-4 (IUI) & MW938640 & This study \\
\hline Bonin Islands, Japan & A. Goto and M. Ito & AB002618 & \\
\hline Yomitan, Okinawa Island, Japan & Kokubugata 2492 (HAST) & AB598563 & Nakamura et al. (2012) \\
\hline \multicolumn{4}{|l|}{ Crepidiastrum platyphyllum (Franch. \& Sav.) Kitam. 절영풀 } \\
\hline Arasaki, Kanagawa, Honshu, Japan & $A S-C R 1193$ (TNS) & AY876259 & Saito et al. (2006) \\
\hline Nagahama, Kanagawa, Honshu, Japan & N2-CR 1197 (TNS) & AY876260 & Saito et al. (2006) \\
\hline Bishyamon, Kanagawa, Honshu, Japan & $B 2-C R 1242$ (TNS) & AY876262 & Saito et al. (2006) \\
\hline Kurosaki, Kanagawa, Honshu, Japan & $K 2-C R 1266$ (TNS) & AY876263 & Saito et al. (2006) \\
\hline \multicolumn{4}{|l|}{ Crepidiastrum ×muratagenii H. Ohashi \& K. Ohashi 홍도고들빼기 } \\
\hline $\begin{array}{l}\text { Graves around Cheong-eo Mireuk, Hongdo Island, Sinan-gun, } \\
\text { Jeollanam-do, Korea }\end{array}$ & Y. J. Jang 200918-11 (IUI) & MW938638 & This study \\
\hline $\begin{array}{l}\text { Yangsanbong ridge, Hongdo Island, Sinan-gun, Jeollanam-do, } \\
\text { Korea }\end{array}$ & Y. J. Jang 201028-4 (IUI) & MW938643 & This study \\
\hline $\begin{array}{l}\text { Yangsanbong ridge, Hongdo Island, Sinan-gun, Jeollanam-do, } \\
\text { Korea }\end{array}$ & Y. J. Jang 201028-6 (IUI) & MW938644 & This study \\
\hline $\begin{array}{l}\text { Gitdaebong ridge, Hongdo Island, Sinan-gun, Jeollanam-do, } \\
\text { Korea }\end{array}$ & Y. J. Jang 201029-3 (IUI) & MW938646 & This study \\
\hline \multicolumn{4}{|l|}{ Youngia japonica (L.) DC. 뽀리뱅이 } \\
\hline Rongjing, Sichuan, China & X. F. Gao11605 (CDBI) & KC968024 & Peng et al. (2014) \\
\hline
\end{tabular}


extracted DNA was electrophoresed on a $1 \%$ agarose gel to confirm the presence or absence of DNA, and the concentration and quality of DNA were confirmed using a NanoDrop ND1000 (NanoDrop Technologies, Wilmington, DE, USA). We used PCR amplification of the ITS of the nuclear ribosomal DNA. Primer and PCR conditions were as described in Saito et al. (2006). The PCR products were visualized on $1 \%$ agarose gels and sequenced using an ABI 3730xl DNA analyzer (Applied Biosystems, Foster City, CA, USA). The determined sequences were deposited in the Genbank (accession nos. MW938634-MW938646). Additionally, the nuclear ribosomal ITS sequences of Japanese and Chinese individuals deposited in GenBank were used for the ITS analysis (Table 1).

\section{Phylogenetic analysis}

The analyzed nucleotide sequences were determined after checking the chromatogram using Geneious R 7.1.9 (Biomatters Ltd., Auckland, New Zealand). All sequences were aligned using the MUSCLE software (Edgar, 2004). Maximum likelihood trees based on ITS data were constructed using the WIQ-TREE Server (http://iqtree.cibiv.univie.ac.at/) (Trifinopoulos et al., 2016), based on user-friendly web servers for IQ-TREE 1.5 (Nguyen et al., 2015). Each aligned sequence dataset was tested to determine the best-fit model by using W-IQ-TREE with the Akaike criterion, and new model selection procedures. TIM3e was confirmed as the best-fit model for the ITS. We evaluated the node supported by 1,000 ultrafast bootstrap replicates (UFBS) (Minh et al., 2013). As an outgroup, Youngia japonica (L.) DC., which is most closely related to the genus Crepidiastrum, was used (Kilian et al., 2009).

\section{Results and Discussion}

\section{Observation of morphological traits}

According to Pak and Kawano (1992), C. denticulatum is a herb, lacking radical leaves during the flowering season, membranous cauline leaves with acute serrations, 13-15 florets, and short and shout beaked achenes. In contrast, $C$.

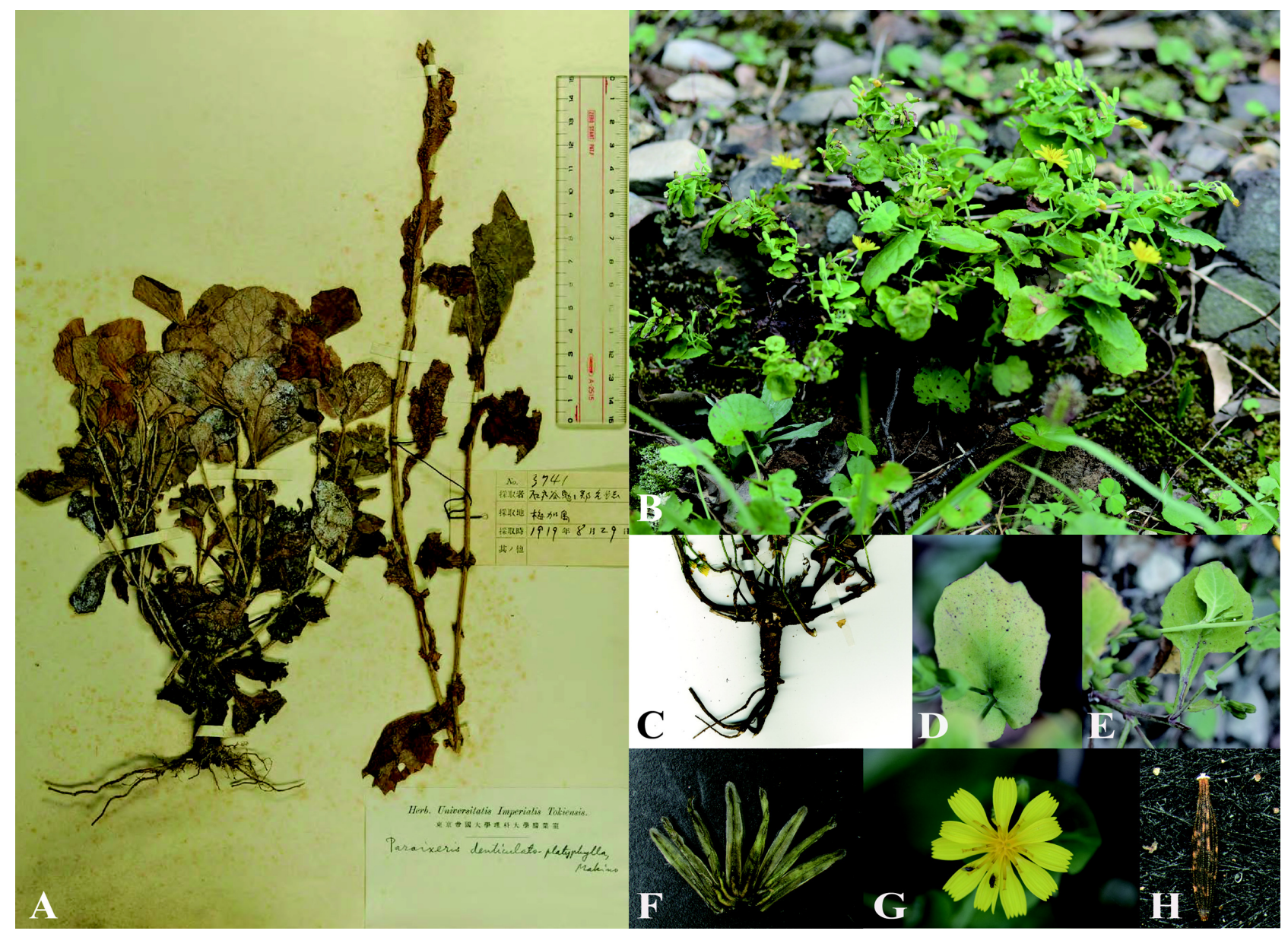

Fig. 1. Crepidiastrum $\times$ muratagenii from Hongdo Island. A. Specimen (29 Aug 1919, Ishidoya, T. \& T. H. Chung 3741 TI). B. Habit. C. Stem and rhizome. D, E. Cauline leaf. F. Involucral bracts. G. Flowers. H. Achene. 
Table 2. Comparison of the morphological characters among Crepidiastrum denticulatum, C. lanceolatum, C. platyphyllum and the Hongdo Island plants.

\begin{tabular}{|c|c|c|c|c|}
\hline & C. denticulatum & C. lanceolatum & C. platyphyllum & Hongdo plants \\
\hline Habit & Herbs & Subshrubs & Subshrubs & Subshrubs \\
\hline Stem & Solitary, erect, branched & $\begin{array}{l}\text { Caudex stout, short, } \\
\text { rhizomelike }\end{array}$ & $\begin{array}{l}\text { Caudex stout, short, } \\
\text { rhizomelike }\end{array}$ & $\begin{array}{c}\text { Caudex stout, short, erect, } \\
\text { branched }\end{array}$ \\
\hline Radical leaf & $\begin{array}{l}\text { Radical leaves withered } \\
\text { during flowering season }\end{array}$ & $\begin{array}{l}\text { Rosulate leaves ovate to } \\
\text { narrowly so, rarely elliptic }\end{array}$ & $\begin{array}{c}\text { Rosulate leaves obovate to } \\
\text { obovate, elliptic }\end{array}$ & $\begin{array}{c}\text { Radical leaves withered during } \\
\text { flowering season }\end{array}$ \\
\hline Cauline leaf & $\begin{array}{l}\text { Membranous texture with } \\
\text { acute serrations }\end{array}$ & $\begin{array}{l}\text { Thicker texture without } \\
\text { serration }\end{array}$ & $\begin{array}{l}\text { Thicker texture without } \\
\text { serration }\end{array}$ & $\begin{array}{c}\text { Membranous texture with acute } \\
\text { serrations }\end{array}$ \\
\hline $\begin{array}{l}\text { No. of involucral } \\
\text { bracts }\end{array}$ & 8 & 8 & 5 & 8 \\
\hline No. of florets & $13-15$ & $8-12$ & 5 & $10-12$ \\
\hline Achene & With short and shout beak & Beakless & Beakless & With short and shout beak \\
\hline
\end{tabular}

lanceolatum and C. platyphyllum are subshrubs, persisting radical leaves, and thicker cauline leaves with entire and beakless achenes. In addition, $C$. lanceolatum has 8 inner involucre bracts, 8-12 florets, and C. platyphyllum has 5 inner involucre bracts, and 5 florets. As a result of observations, Hongdo Island individuals showed mixed characteristics of $C$. denticulatum and C. lanceolatum (Fig. 1, Table 2). Hongdo Island individuals were similar to $C$. lanceolatum in a shrub with caudex stout, 8 inner involucre bracts, florets less 10-12 (13-15 in C. denticulatum), but differed from C. lanceolatum by having radical leaves withered during the flowering season, membranous cauline leaves with acute serrations, and short and shout beaked achenes as $C$. denticulatum.

\section{Survey of geographical distribution}

To confirm the distribution of Hong-do-go-deul-ppae-gi and its related taxa, Hong-do-go-deul-ppae-gi was collected from Hongdo and Geomundo Islands in Korea. Crepidiastrum lanceolatum occurs in rocky areas along the seashore of Jeju and the southern coast of Korea, while $C$. denticulatum occurs on sunny slopes and roadsides in the mountains of all Korean provinces. According to recent literature, C. platyphyllum is known as a Japanese endemic plant distributed in Chiba Prefecture, Kanagawa Prefecture, and Shizuoka Prefecture in Japan (Pak and Kawano, 1992; Koyama, 1995; Kadota et al., 2017). Therefore, it is highly likely that a hybrid of $C$. lanceolatum and C. denticulatum, rather than C. platyphyllum and $C$. denticulatum, would occur on Hongdo Island (Fig. 2). In addition, the T. Ishidoya specimen (Ishidoya, T. \& T. H. Chung $3741 \mathrm{TI})$ was re-identified as a hybrid of $\times$ Crepidiastrixeris denticulato-lanceolata Kitam. (nom. illeg.) [=C. ×muratagenii H. Ohashi \& K. Ohashi] by Kitamura (1955).

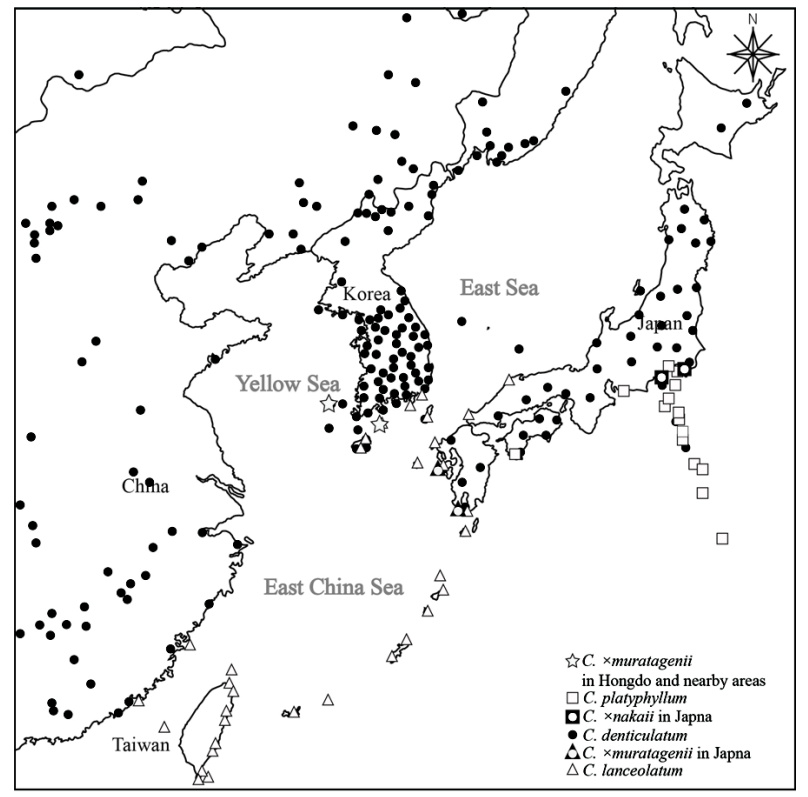

Fig. 2. Distribution of Crepidiastrum 5 taxa in East Asia (Source: GBIF [http://www.gbif.org], The Korea National Biospecies Information System [http://www.nature.go.kr], Science Museum Net [http://science-net.kahaku.go.jp], the Chinese Virtual Herbarium [http://www.cvh.ac.cn]).

\section{Phylogenetic analysis of ITS sequences}

In the ITS phylogenetic tree, the 4 taxa of the genus Crepidiastrum were divided into two clades; $C$. lanceolatum and C. platyphyllum, C. denticulatum, and Hongdo Island individuals, but each taxon did not form a monophyletic group. Significant differences did not exist between the nucleotide sequences of the Hongdo Island individuals and the Korean C. denticulatum (Fig. 3). For that reason, Saito et al. (2006) reported that $C$. $\times$ nakaii in $\mathrm{F}_{1}$ status showed an additivity of parent sequences at the nrDNA locus, but in $\mathrm{F}_{2}$ status showed 


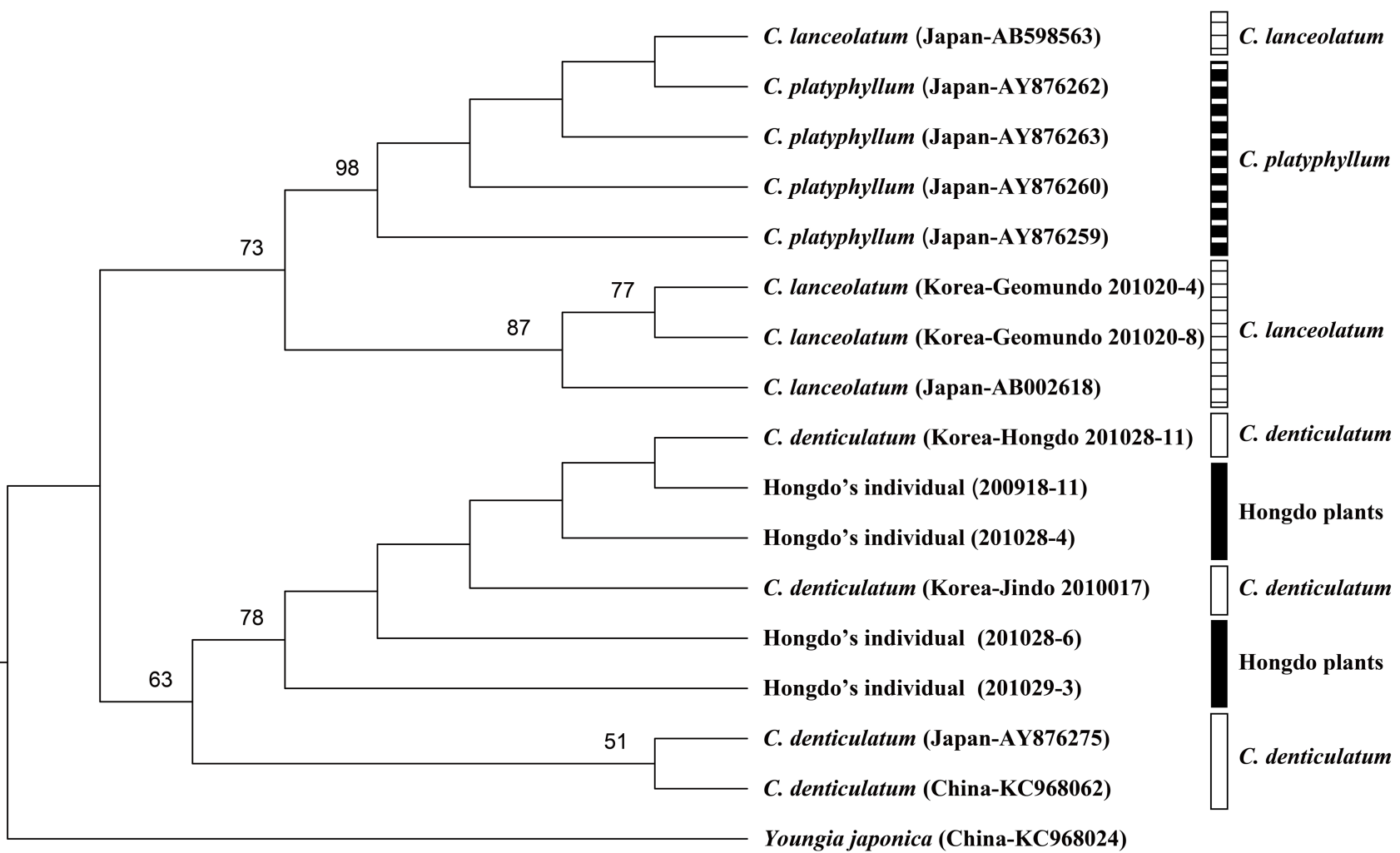

Fig. 3. Maximum likelihood (ML) tree based on nuclear ribosomal ITS sequences of Crepidiastrum 4 taxa. Bootsrap values ( $>50 \%)$ are indicated above branches.

either the ITS sequences of one parent only, or one predominant ITS type, despite the intermediate morphology between $C$. platyphyllum and $C$. denticulatum. These results can be explained through a backcross to $C$. denticulatum or segregating of $\mathrm{F}_{2}$. Further studies are required to understand the taxonomic identity of this species.

\section{Origin and scientific name of the plant}

Based on our investigations on morphological traits and geographical distribution, the origin of "Hong-do-go-deulppae-gi" recorded in Hongdo Island should be regarded as a hybrid between $C$. denticulatum and $C$. lanceolatum, and not a hybrid between $C$. denticulatum and $C$. platyphyllum. Therefore, that the scientific name of the plant should be assigned as $C$. $\times$ muratagenii, a hybrid between $C$. denticulatum and C. lanceolatum.

ORCID: Young-Jong JANG https://orcid.org/0000-0001-62572424; Byoung-Hee CHOI https://orcid.org/0000-0002-9234-9052

\section{Acknowledgments}

This work was supported by the National Research Foundation of Korea (NRF-2018R1D1A1B07043030).

\section{Conflict of Interest}

The authors declare that there are no conflicts of interest.

\section{Literature Cited}

Arnold, M. L. 1997. Natural Hybridization and Evolution. Oxford University Press, New York, 228 pp.

Brochmann, C., L. Borgen and O. E. Stabbetorp. 2000. Multiple diploid hybrid speciation of the Canary Island endemic Argyranthemum sundingii (Asteraceae). Plant Systematics and Evolution 220: 77-92.

Edgar, R. C. 2004. MUSCLE: Multiple sequence alignment with high accuracy and high throughput. Nucleic Acids Research 32: 1792-1797.

Francisco-Ortega, J., R. K. Jansen and A. Santos-Guerra. 1996. Chloroplast DNA evidence of colonization, adaptive radiation, and hybridization in the evolution of the Macronesian flora. Proceedings of the National Academy of Sciences of the United States of America 93: 4085-4090.

Fuertes-Aguilar, J, M. F. Ray, J. Francisco-Ortega, A. Santos- 
Guerra and R. K. Jansen. 2002. Molecular evidence from chloroplast and nuclear markers for multiple colonizations of Lavatera (Malvaceae) in the Canary islands. Systematic Botany 27: 74-83.

Grant, V. 1981. Plant Speciation. 2nd ed. Columbia University Press, New York, 563 pp.

Howarth, D. G. and D. A. Baum. 2005. Genealogical evidence of homoploid hybrid speciation in an adaptive radiation of Scaevola (Goodeniaceae) in the Hawaiian islands. Evolution 59: 948-961.

Jorgensen, T. H. and J. M. Olesen. 2001. Adaptive radiation of island plants: Evidence from Aeonium (Crassulaceae) of the Canary Islands. Perspectives in Plant Ecology, Evolution and Systematics 4: 29-42.

Kadota, Y., H. Setoguchi, A. Soejima, T. Touma, T. Morita and K. Yonekura. 2017. Asteraceae. In Wild Flowers of Japan, Vol. 5. Convolvulaceae to Caprifoliaceae. Ohashi, H., Y. Kadota, H. Kihara, J. Murata and K. Yonekura (eds.), Heibonsha, Tokyo. Pp. 198-369. (in Japanese)

Kilian, N., B. Gemeinholzer and H. W. Lack. 2009. Cichorieae. In Systematics, Evolution and Biogeography of Compositae. Funk, V. A., A. Susanna, T. F. Stuessy and R. J. Bayer (eds.), International Association for Plant Taxonomy, Vienna. Pp. 343-383.

Kitamura, S. 1937. Genera Lactuca, Ixeris and Crepidiastrum. Acta Phytotaxonomica et Geobotanica 6: 235-238. (in Japanese)

Kitamura, S. 1955. Compositae Japonicae. Pars Quarta. Memoirs of the College of Science, University of Kyoto, Series B 22: $77-126$.

Koyama, H. 1995. Asteraceae (Compositae). In Flora of Japan, Vol. 3b. Angiospermae, Dicotyledoneae, Sympetalae (b). Iwatsuki, K., T. Yamazaki, D. E. Boufford and H. Ohba (eds.), Kodansha, Tokyo. Pp. 1-170.

Lee, T. B. 1969. Plant resources in Korea. Bulletin of Seoul National University (Biological Agriculture) 20: 158-159. (in Korean)

Lee, W. T. 1996. Lineamenta Florae Koreae. Academy Publishing Co., Seoul, 1688 pp. (in Korean)
Minh, B. Q., M. A. T. Nguyen and A. von Haeseler. 2013. Ultrafast approximation for phylogenetic bootstrap. Molecular Biology and Evolution 30: 1188-1195.

Nakamura, K., K.-F. Chung, C.-J. Huang, Y. Kono, G. Kokubugata and C.-I. Peng. 2012. Extreme habitats that emerged in the Pleistocene triggered divergence of weedy Youngia (Asteraceae) in Taiwan. Molecular Phylogenetics and Evolution 63: 486-499.

Nguyen, L.-T., H. A. Schmidt, A. von Haeseler and B. Q. Minh. 2015. IQ-TREE: A fast and effective stochastic algorithm for estimating Maximum-likelihood phylogenies. Molecular Biology and Evolution 32: 268-274.

Ohashi, H. and K. Ohashi. 2007. Hybrids in Crepidiastrum (Asteraceae). Journal of Japanese Botany 82: 337-347.

Ohwi, J. 1965. Flora of Japan. English edition. Smithsonian Institution, Washington, D.C., 1067 pp.

Pak, J.-H. and S. Kawano. 1992. Biosystematic studies on the genus Ixeris and its allied genera (Compositae-Lactuceae) (IV): Taxonomic treatments and nomenclature. Memoirs of the Faculty of Science, Kyoto University, Series of Biololgy 15: 29-61.

Peng, Y.-L., Y. Zhang, X.-F. Gao, L.-J. Tong, L. Li, R.-Y. Li, Z.-M. Zhu and J.-R. Xian. 2014. A phylogenetic analysis and new delimitation of Crepidiastrum (Asteraceae, tribe Cichorieae). Phytotaxa 159: 241-255.

Rieseberg, L. H. 1997. Hybrid origins of plant species. Annual review of Ecology and Systematics 28: 359-389.

Saito, Y., M. Möller, G. Kokubugata, T. Katsuyama, W. Marubashi and T. Iwashina. 2006. Molecular evidence for repeated hybridization events involved in the origin of the genus $x$ Crepidiastrixeris (Asteraceae) using RAPDs and ITS data. Botanical Journal of the Linnean Society 151: 333-343.

Seehausen, O. 2004. Hybridization and adaptive radiation. Trends in Ecology and Evolution 19: 198-207.

Trifinopoulos, J., L.-T. Nguyen, A. von Haeseler and B. Q. Minh. 2016. W-IQ-TREE: A fast online phylogenetic tool for Maximum likelihood analysis. Nucleic Acids Research 44: W232W235. 


\section{홍도고들빼기의 분류학적 실체 \\ 장영종 · 최병희 ${ }^{*}$ \\ 인하대학교 생명과학과}

적 요: 고들빼기속에 속하는 홍도산 홍도고들빼기의 학명은 이고들빼기와 절영풀의 잡종인 Crepidiastrum $\times n a k a i i$ 로 기록되어 왔다. 홍도 식물상을 조사하는 과정에서 홍도고들빼기의 분류학적 실체를 재검토하였다. 이를 위해 홍도고들빼기의 형태적 특징과 지리적 분포 및 internal transcribed spacer (ITS) 염기서열을 고들빼 기속 근연종들과 비교하였다. 형태적 특성 조사에서, 홍도고들빼기는 짧고 굵은 아관목성 줄기와 8 개의 내총 포편 및 10 내지 12 개의 소화수를 갖는 점에서 갯고들빼기와 유사한 반면, 개화기에 시드는 뿌리잎과 막질로 예 거치인 줄기잎 및 부리가 있는 수과 형태 등에서는 이고들빼기와 유사하였다. 한편 이고들빼기와 갯고들빼기는 홍도와 인근 섬 지역에 자라지만, 절영풀은 분포하지 않는다. 이러한 형태 및 분포 조사결과, 홍도고들빼기의 학 명은 이고들빼기와 절영풀의 잡종인 C. ×nakaii가 아니라, 이고들빼기와 갯고들빼기의 잡종인 C. ×muratagenii로 판단된다. 하지만, ITS 염기서열은 조사된 종들을 구별할 수 있는 해상력을 보여주지 못하였다.

주요어: 홍도고들빼기, 홍도, 고들빼기속, 형태적 특징, 지리적 분포 